\title{
Effect of Security Challenges on Library Resources in the Federal University of Lafia Library, Nasarawa State
}

\author{
Kingsley Emmanuel Enyi, Federal University of Lafia, Nigeria* \\ Jacob Fagga Tsegba, Federal University of Agriculture, Nigeria
}

\begin{abstract}
The study looks at security challenges, causes and effects of security challenges on the resources, types of collection that are more vulnerable to security breaches, challenges encountered in combating the breaches, measures to reduce and address security breaches in the Federal University of Lafia library. The study uses survey research design. The population examined is 30 library staff and 100 undergraduate students in the Federal University of Lafia, summing total population to 130. Data was collected using a questionnaire titled effect of security challenges on library resources in Federal University of Lafia library. Random sampling technique was used for the study. Mean tables, frequencies, and percentage were used to analyse data. It shows that the library is faced with the challenges of book theft, non-return of materials, mutilation, overdue books, shelving of books. Recommendations include increased security in the library by supervision, patrolling/surveillance, buy copiers, and installed security gadgets in the library premises and fencing.
\end{abstract}

\section{KEYWORDS}

Library Resources, Security Challenge, University Libraries

\section{INTRODUCTION}

A library is a collection of sources of information and similar resources made accessible to a defined community for reference or borrowing. It provides physical or digital access to materials and may be a physical building or room or a virtual space or both. A library houses books and stores other forms of knowledge and information resources to meet the different information needs of its patrons (Udensi \& Akor, 2014). Information resources are widely spread out and cut across academic disciplines. As such, this exposes the library to all kinds of attacks by its day to day patrons in the university. It is in this regard that it is important to ensure safety and security of the information resources from its vulnerability patrons. Therefore, ensuring good security and safety of the collections is as important as providing effective services in response to the information needs of the user community.

In trying to provide effective services to the community, the library preserves materials and information resources for all languages, occupations, religions, and social, economic and cultural aspects of the community it serves (IFLA/UNESCO, 2011). Libraries act as providers of regular and current information managed by staff with different attitudes and perceptions. The future and sustainability of any library depends more on its librarians and staff than any other factors or 
components (Blackwell, 2000). This is because library staff have full responsibilities of protecting the information resources from mutilation and from being stolen by its patrons whether they are libraries at universities or other institutions.

University libraries are libraries found in universities (Ogbonna \& Okenyi, 2014). The university libraries fall under the category of academic libraries. These are libraries established, owned and funded by the parent institution which is the university (Ode \& Omokaro, 2017). The university library programs range from postgraduate, undergraduate, sub degree to certificate courses whose objectives are geared towards the quality of services they render to its patrons. However, this depends on the quality of staff responsible for effective and efficient service delivery in an institution. The information resources are broad and varied from one discipline to another to support the educational objectives. Library services can only be achieved through the availability and proper handling of its numerous collections. This is the reason why Anuobi and Okoye (2008) state that "university libraries are faced with the hybrid challenges of managing resources and are challenged to acquire the necessary skills needed for the adequate security of the library's collection or resources both in print and non-print format." Chaney and MacDougail (2004) state that library collections are vulnerable to abuse of one sort or another, and library managers need to keep this characteristic well to the forefront of the library. Ensuring effective use, longevity and accessibility of library resources makes an effective program of collection security necessary.

Security challenges of library collections are as old as the library itself. Antiwi (2009) states that security challenges such as book theft started when the Persians went to Egypt and withdrew papyrus from the Library of Ramses II without stopping for any formalities at the charging desk. They thus began this practice which has continued to torment libraries ever since.

A security challenge refers to the threat posed to the library resources by its day to day patrons. Collection security refers to a process designed to protect library collections against un-authorized removal or loss by library patrons. This involves protecting resources against disasters as well as thieves or intruders (Ajegbomogun, 2004). Collection security management in libraries can be conceptualized to mean the overall manner in which collection security policies, programs, procedures, or measures are deployed to mitigate risk and ensure access. Crime is increasing in a spectacular and frightening rate in university libraries (Lawal, 2010). Activities such as vandalization, mutilation, defacement, theft, hiding of books, verbal and physical abuse, harassment and other criminal activities are some of the challenges regularly encountered by the library resources found in the library. It is therefore vital that today's libraries be positioned to be able to confront these challenges in an objective, analytical and professional manner without displeasing the library users. The act of stealing, mutilating and vandalizing library resources is no doubt also spreading among library patrons (Ugah, 2007). These negative acts not only cause some immediate damage but also have longer effects on those who witness them and the library's collection at large.

\section{STATEMENT OF THE PROBLEM}

Library staff are often faced with the challenges of theft, mutilation and vandalization by many of its patrons in university libraries. The effect of these challenges varies from one university library to the other but seems to be a universal problem to all libraries (Akor, 2003). These named security challenges can negatively affect the operations and service delivery of the library. Such effects as a decrease in the number of collections, deterioration of the materials as a result of manhandling and misplacement of information materials deny readers access to the resources among many others (Edoka, 2010).

The importance of information resources in the library cannot be overemphasized. This is because they are the backbone of libraries as there cannot be a library without resources. Information resources create awareness to the users, develop users intellectually, wipes away uncertainties, impact knowledge 
through research and help both teachers and students in teaching and learning (Evans, 2000). These resources are both in print and non-print and are all subject to security challenges (Greenstein, 2000).

In spite of the importance of library resource, researchers have observed that library staff in the Federal University of Lafia Library, Nasarawa State seem not to be aware of security challenges in their library. It could be that these library staff are not aware of what collection security challenges can cause in the library. If these challenges are not identified and tackled urgently, library resources will suffer heavy casualties in terms of theft and damages with setbacks in its services.

Although, many researchers like Anunobi \& Okoye (2008) and Ajegbomogun (2004) have carried out studies on related topics, none has been done in the Federal University of Lafia Library, Nasarawa State which has created a gap in literature. It is against this background that this study intends to investigate the effect of security challenges on library resources in Federal University of Lafia, Nasarawa State.

\section{OBJECTIVES OF THE STUDY}

The general objective of the study is to determine the effect of security challenges on library resources in the Federal University, Lafia. Specifically, the study set to

1. identify security challenges encountered in the Federal University of Lafia;

2. ascertain the causes of security challenges in the Federal University of Lafia Library;

3. determine the effect of security challenges on information resources in the Federal University of Lafia Library;

4. ascertain the types of library resources that are more vulnerable to security breaches in the Federal University of Lafia Library;

5. Identify challenges encountered by library staff in combating security challenges in the Federal University of Lafia Library;

6. determine strategies to overcome security breaches in the Federal University of Lafia Library.

\section{LITERATURE REVIEW}

Library security challenges are regarded as acts committed by users of the libraries against library resources. These acts could be theft, mutilation, defacement of the collection, arson and mis-shelving. According to Jato (2005), scandalous behaviors such as theft and mutilation, hiding library materials, refusal to return overdue borrowed materials, drinking and eating in the library, vandalism and defacement of library collections, arson, negligence to library policies as well as various disaster such as fire and flood caused by human factors, among others have become a common occurrence in university libraries and if this is not checked, it would lead to serious drought of information materials in the library.

Most university libraries in developing countries, including Nigeria, lack security measures. This encourages library patrons to perform such acts (Jato, 2005). According to Momodu (2002), university libraries have been faced with varying degrees of criminal behaviors in the use of their resources especially materials, and to some extent manpower. The extent of this problem varies from one library to another. In some cases, the dimension of the problem is so restricted that it seems nonexistent, in some others the dimension is so immense that it calls for serious concern.

The findings of the study conducted by Momodu (2002) on the delinquent readership in selected urban libraries in Nigeria revealed that every library has a delinquent client problem and that there is no direct correlation between the type of library and the extent of the problem. As such, the problem seems to be universal. Ajegbomogun (2004) acknowledged that, some library users display disruptive 
or criminal behaviors within the library surroundings and this can cause security problems in the library.

The issue of collection security breaches is of growing concern to academic libraries and librarians. As a result, there are studies on problems concerning library security in university libraries. Ugah (2007) in one of his studies in Michael Okpara University of Agriculture, Umudike Nigeria considers library security threat as formidable obstacles to information access and use. Such acts, he states, are serious problems that can result in user dissatisfaction. He identified major security issues in libraries to include theft and mutilation, vandalism, damage and disaster, over borrowing or delinquent borrowers, and purposely displacing arrangement of materials. Literature on collection security have shown that security breaches often happen where there is security and crime challenges in university libraries in Nigeria when the library premises are left unsecured. Oder (2004) maintains that security measures such as supervision, patrolling, and surveillance are lacking in libraries and keys are kept unsecured, if not in plain sight of the users. He agrees that security personnel inefficiency is also a big avenue to library crime, especially in academic libraries. Non-return of library materials is a threat to the effective use of resources, and to avoid this libraries should create policies to ensure library resources are used effectively.

Momodu (2002) and Ajegbomogun (2004) maintain that library crimes also include varying degrees of delinquency. Libraries in Nigeria are performing a great portion of their activities traditionally. A recent study by Ogbonyomi (2011) has shown that crime against library collections, otherwise known as information resources, is on the increase in a number of Nigerian university libraries. It was observed that there was no significant relationship found between the security measures adopted and the crime rate. The rate of declining budgets and higher subscription costs facing universities is making it seemingly impossible for libraries to meet the rising information needs of university students, let alone allowing the available collections lost. As a matter of fact, unlawful activities against information resources are formidable obstacle to information access and use, not only posing a serious problem that needs urgent attention, but also constituting a big cost to scholarship (Ugah, 2007). Ifidon (2000) states that mutilation and theft in libraries is a menace that has persisted, and it is indeed a global problem, the worsening state of libraries in Nigeria appears to have aggravated its intensity and the consequent detrimental impact. Theft is the act of stealing from the library's collection, and it has been argued that the theft of archival materials has become a problem of great proportions to the library resources.

More importantly, from the literature reviewed, it is obvious that the issue of library resources and effect of security challenges in the university libraries have been adequately addressed in Nigeria. The review has also shown that all the studies available are on academic libraries of other states in Nigeria and beyond. None of these studies has written in specific terms, library resources and effect of security challenge in Federal University of Lafia Library in Nasarawa State. This is the gap the study intends to fill.

\section{METHODOLOGY}

The study was conducted using a survey research design methodology. According to Osuala (2005) a survey research studies both large and small populations by selecting and studying samples from the population in order to discover the relative incidence, distribution and interrelations of sociological and psychological variables. The Federal University of Lafia Library constitutes the research environment for the study. The population of the study is comprised of library staff and students. The total population of library staff in the institution of study was thirty (30), while that of the students was seven thousand eight hundred and sixty (7860). A census study, that is, total enumeration of the staff population was adopted because the number is small and manageable that the researchers can handle. Accidental or convenient sampling technique was used to obtain data from one hundred (100) students, which resulted to the sample size of one hundred (100) students. Consequently, the 
sample size of the study comprises of thirty (30) library staff and hundred (100) students in Federal University of Lafia, giving a total of one hundred and thirty (130) sample size used for the study.

Accordingly, the data for the study was collected using a questionnaire by the researchers through personal contact to ensure high percentage return. The questionnaire was administered and collected directly on the spot. University staff and students served as respondents. The questionnaire was randomly distributed to students during library open hours while that of the library staff were distributed during their working hours in their offices. The total number of one hundred and thirty (130) questionnaires distributed were all returned. Observation was also used to collect data for the study. Observation was undertaken to physically assess some information resources in the libraries as adopted in this study. The responses obtained from the respondents in the university form the data for analysis. The data was treated statistically in accordance with the question generated from the study, and showing mean, percentages and tables used in the analysis.

\section{Response Rate}

One hundred and thirty (130) copies of the questionnaire were administered to the staff and students of the Federal University of Lafia and were all returned, making a response rate of $100 \%$.

\section{Results, Data Analysis and Interpretation}

In order to determine the security issues of the study, respondents were asked to identify with some statements that could reveal the type or nature of crime observed in their library. To adequately present the findings of the study the percentages option such as agree/disagree was used in Table 1, 2 and 4 to rate the responses of respondent on the types of collection security breaches, causes of crime in the library and the types of collections vulnerable to security breaches in percentages as presented in the tables. Table 3 and 5 were used to rate the responses such as high extent/low extent like the effect of security challenges on information resources and challenges encountered by library staff in combating security breaches was subjected to analysis using mean and standard deviation as presented in the tables. While Table 6 suggested strategies in enhancing security measures were used in presenting the results in the study.

Table 1. Types of collection Security Breaches

\begin{tabular}{|l|l|l|l|l|l|}
\hline S/N & Security Breaches & Agreed & Pp Percentage & Disagree & Percentage \\
\hline 1 & Book theft & 100 & $76.9 \%$ & 30 & $23.1 \%$ \\
\hline 2 & Book mutilation & 120 & $92.3 \%$ & 10 & $7.7 \%$ \\
\hline 3 & Keeping overdue books & 90 & $69.2 \%$ & 40 & $30.8 \%$ \\
\hline 4 & $\begin{array}{l}\text { Using fake I.D card to borrow } \\
\text { books }\end{array}$ & 60 & $46.1 \%$ & 70 & $53.9 \%$ \\
\hline 5 & Mis-shelving of books & 125 & $96.1 \%$ & 5 & $3.8 \%$ \\
\hline 6 & Noise making in the library & 2 & $1.5 \%$ & 128 & $98.5 \%$ \\
\hline 7 & Eating in the library & 18 & $13.8 \%$ & 112 & $86.2 \%$ \\
\hline
\end{tabular}

Table 1 reveals that among the items categorized under the types of collection security breaches in the library are mis-shelving of books with a percentage of 96.1 , book mutilation with $92.3 \%$ followed by book theft which scored $76.9 \%$, while keeping overdue books indicated $69.2 \%$ by respondents. Eating in the library, using fake ID cards to borrow books and noise making in the library were rejected by respondents as not security challenges of the collection with a percentage less than fifty. 
Table 2. Causes of Crime in the Library

\begin{tabular}{|l|l|l|l|l|l|}
\hline S/N & Causes & Agreed & Percentage & Disagree & Percentage \\
\hline 1 & Insufficient library resources for users & 120 & $92.3 \%$ & 10 & $7.7 \%$ \\
\hline 2 & Selfish interest of the culprits & 125 & $96.2 \%$ & 5 & $3.8 \%$ \\
\hline 3 & $\begin{array}{l}\text { Lack of proper orientation to users on the use } \\
\text { of library resources }\end{array}$ & 75 & $57.7 \%$ & 55 & $42.3 \%$ \\
\hline 4 & Lack of photocopying services & 102 & $78.5 \%$ & 28 & $21.5 \%$ \\
\hline 5 & Financial constraint of libraries & 90 & $69.2 \%$ & 40 & $30.8 \%$ \\
\hline 6 & AbAbsence of security patrol in the library & 82 & $63.1 \%$ & 48 & $36.9 \%$ \\
\hline
\end{tabular}

From Table 2 above, the items listed under causes of crime in the library revealed that majority of the respondents (96.2\%) indicated that it is selfish interest of the culprits that causes security breaches in the library, follow by $(92.3 \%)$ who indicated that insufficient library resources for users make users to commit crime such as stealing and mutilation in the library. This is followed by lack of photocopying machines $(78.5 \%$ ) while $69.2 \%$ indicated that financial constraint causes users to commit crime in the libraries, $63 \%$ indicated lack of security patrol in the library and $57.7 \%$ were said to have committed crime in the library because of lack of proper orientation given to users on how to use library resource. The summary of responses in Table 2 revealed that majority of the respondents indicated that selfish interest of the culprits, insufficient library resources in the library, lack of photocopying machine and financial constraint mostly make users to commit crime of different types in the library.

Table 3. Effect of Security Challenges on Information Resources

\begin{tabular}{|l|l|l|l|l|l|l|}
\hline S/N & Effects of Security challenge & VHE & HE & LE & VLE & Mean \\
\hline 1 & $\begin{array}{l}\text { Users are unable to use Information } \\
\text { resources because of their defacement }\end{array}$ & 38 & 45 & 25 & 22 & 2.76 \\
\hline 2 & $\begin{array}{l}\text { Inability of users to effectively make use } \\
\text { of the information resources have as a } \\
\text { result of mutilation }\end{array}$ & 35 & 55 & 23 & 17 & 2.83 \\
\hline 3 & $\begin{array}{l}\text { Damage of information resources as a } \\
\text { result of manhandling by users }\end{array}$ & 40 & 57 & 13 & 20 & 2.90 \\
\hline 4 & $\begin{array}{l}\text { Mis-shelving of resources can deny } \\
\text { readers access to the materials }\end{array}$ & 35 & 40 & 30 & 25 & 2.65 \\
\hline 5 & $\begin{array}{l}\text { Inabilities to return overdue books deny } \\
\text { users temporary access to the resources }\end{array}$ & 35 & 45 & 20 & 30 & 2.65 \\
\hline 7 & $\begin{array}{l}\text { Decrease of library collection as a result } \\
\text { of theft }\end{array}$ & 45 & 50 & 20 & 15 & 2.96 \\
\hline
\end{tabular}

Key: Very High Extent (VHE), High Extent (HE), Low Extent (LE) and Very Low Extent (VLE) 
Responses on the effects of security challenges on information resources in the Federal University of Lafia indicated a mean score of 2.96, indicating that stolen library resources impact a collection with very high effect. Also, manhandling causes damage of library resources scored 2.90, negative effect on the use of resources as a result of mutilation indicated 2.83, inability of users to make good use of the resources as a result defacement 2.76, while mis-shelving and inability to return overdue books resulting to denying access to the resources scored 2.65 each. 2.52 of respondents agreed that security breaches of information resources bring about a lack of confidence on the information resources by the users. All the items scored 2.5 and above indicating that they have negative effect on the information resources.

Table 4. Types of Collections Vulnerable to Security Breaches

\begin{tabular}{|l|l|l|l|l|l|}
\hline S/N & Types of collection & Agreed & Percentage & Disagreed & Percentage \\
\hline 1 & Textbooks & 120 & $92.3 \%$ & 10 & $7.7 \%$ \\
\hline 2 & Serials/periodical collections & 95 & $73.1 \%$ & 35 & $26.9 \%$ \\
\hline 3 & Reference collections & 95 & $73.1 \%$ & 35 & $26.9 \%$ \\
\hline 4 & Reserve collections & 60 & $46.2 \%$ & 70 & $53.4 \%$ \\
\hline 5 & Non-print collection & 5 & $38.5 \%$ & 125 & 96.2 \\
\hline
\end{tabular}

Table 4 reveals that a majority of the respondents $(92.3 \%)$ indicated that textbooks are most vulnerable to security breaches while $73.1 \%$ reported that serial collections are equally vulnerable to security breaches. $73.1 \%$ of the respondents stated that reference collections and serial collections respectively are also vulnerable to security breaches, $(42.3 \%)$ while $(53.4 \%)$ and (96.2\%) each disagreed that reserve and non-print collections are vulnerable to security challenges.

Table 5. Challenge encountered by Library Staff in Combating Security breaches in the FUL Library

\begin{tabular}{|l|l|l|l|l|l|l|}
\hline S/N & Challenges encountered & VHE & HE & LE & VLE & Mean \\
\hline 1 & $\begin{array}{l}\text { Inadequate staff to man the reader's services } \\
\text { Department. }\end{array}$ & 15 & 30 & 50 & 35 & 2.19 \\
\hline 2 & Unavailability of photocopying services. & 40 & 50 & 25 & 15 & 2.88 \\
\hline 3 & $\begin{array}{l}\text { Lack of security personnel to patrol the } \\
\text { library. }\end{array}$ & 35 & 55 & 18 & 22 & 2.79 \\
\hline 4 & $\begin{array}{l}\text { Lack of modern electronic security gadgets } \\
\text { such as CCTV. }\end{array}$ & 20 & 64 & 18 & 28 & 2.58 \\
\hline 5 & $\begin{array}{l}\text { Lack of awareness of security challenges by } \\
\text { library staff. }\end{array}$ & 15 & 20 & 40 & 55 & 1.96 \\
\hline 7 & Lack of library policy on security check. & 30 & 28 & 40 & 32 & 2.43 \\
\hline 8 & $\begin{array}{l}\text { Lack of a functional Bindery unit to repair } \\
\text { mutilated information resources. }\end{array}$ & 45 & 56 & 22 & 7 & 3.07 \\
\hline
\end{tabular}

Key: Very High Extend (VHE), High Extend (HE), Low Extend (LE) and Very Low Extend (VLE) 
Table 5 above shows that a lack of a functional bindery unit by library staff for the repairs of mutilated books had the highest mean rating of 3.07, indicating the challenge encountered by staff, followed by lack of photocopy services for the library scoring 2.88 , a lack of security personnel to patrol the library had a mean rating of 2.79 , while a lack of modern electronic security gadgets such as CCTV and the lack of training of library staff on security awareness scored 2.58 and 2.52 respectively.

Table 6. Strategies adopted to enhance security measures

\begin{tabular}{|c|c|c|c|c|c|c|}
\hline $\mathbf{S} / \mathbf{N}$ & Strategies. & SA & $\mathbf{A}$ & DA & SDA & MEAN \\
\hline 1 & $\begin{array}{l}\text { There should be a library written security } \\
\text { policy to guide staff. }\end{array}$ & 45 & 55 & 20 & 10 & 3.04 \\
\hline 2 & $\begin{array}{l}\text { Installation of a functional bindery unit in the } \\
\text { Library for the repair of damage resources }\end{array}$ & 37 & 46 & 20 & 27 & 2.72 \\
\hline 3 & $\begin{array}{l}\text { Security guards should be deployed to patrol } \\
\text { the library reading room. }\end{array}$ & 40 & 37 & 30 & 23 & 2.72 \\
\hline 4 & $\begin{array}{l}\text { Introduction of photocopying services in the } \\
\text { library. }\end{array}$ & 45 & 34 & 30 & 21 & 2.79 \\
\hline 5 & $\begin{array}{l}\text { Staff should be trained on the security and } \\
\text { protection of library resources. }\end{array}$ & 32 & 39 & 25 & 34 & 2.53 \\
\hline 6 & $\begin{array}{l}\text { Electronic security system such as CCTV } \\
\text { should be introduced in the library.. }\end{array}$ & 50 & 43 & 20 & 17 & 2.97 \\
\hline
\end{tabular}

Key: Strongly Agreed (SA), Agreed (A), Disagreed (DA) and Strongly Disagreed (SDA)

From Table 6 above, it was indicated by respondents that there should be a written security policy to guide staff which had the highest mean score of 3.04, followed by introduction of electronic security system such as CCTV with 2.97 rating. Introduction of photocopying services recorded a mean of 2.79 while deployment of security guards to the library and introducing manual approaches such monitoring library users scored 2.72 each. Establishment of a bindery unit and training of staff on the protection of information materials were rated 2.65 and 2.53 respectively.

\section{CONCLUSION}

This study examined the effect of security challenges on library resources in the Federal University of Lafia, Nasarawa State. From the findings, it was discovered that print resources are more vulnerable to security challenges and that security breaches of the resources have negative effects on the resources. Since the level of security and crime challenges in the Federal University Lafia Library was discovered to be alarming, there is need for all hands to be on deck in order to eradicate these vices by regular patrol of the library and other security measures. This effort would help to strengthen the life span of the information resources in this library for a sustainable period and the information resources of the library would no longer be de-faced, mutilated, mis-shelved or completely stolen from the library. The eradication of these vices would in turn encourage students to effectively use the library in order to achieve their educational objectives and research work. Failure to deal with these vices will render the library non-functional, and the library services and its profession will suffer a lot of redundancy, which will lead to lack of jobs by library professionals.

\section{Recommendation}

The following recommendations are made bases on the findings for this study: 
1. There should be a written library security policy of the Federal University of Lafia Library for library staff and users' benefits and consumption. This will help in creating awareness on the part of staff and consequences for would be culprits.

2. There should be proper shelving and shelf reading of library resources in the Federal University Lafia Library to avoid misplacement of information for better accessibility of the resources.

3. Photocopying machines should be made available at affordable prices in and around the Federal of University Lafia Library. This would discourage deviants from removing pages of books and other information resources.

4. Patrons should be thoroughly searched before entering and leaving the premises of the Federal of University Lafia Library.

5. Regular staff training and orientation of users on how to prevent the culprits from perpetuating the act within and outside the university library and the consequences that will follow.

6. Electronic security system like the CCTV cameras should be mounted in Federal University of Lafia library.

7. The Federal University of Lafia Library should endeavor to automate their library services and also install effective electronic libraries as this would not only provide current and varieties of information resources in the libraries, but would also mitigate library theft

8. The university building should be fenced to provide more security for both human and material resources. 


\section{REFERENCES}

Adewuyi, O. W., \& Adekanye, E. A. (2011). Strategy for prevention of crime in Nigerian university libraries: The experience of the university of Lagos. Library \& Archival Security, 24(1), 25-37. doi:10.1080/01960075.2011.552315

Ajegbomogun, F. O. (2004). User assessment of library security: A Nigerian university case study. Library Management, 25(8/9), 386-390. doi:10.1108/01435120410562880

Akor, P. U. (2003). Evaluative Study of resources and services of the two university libraries in Makurdi (Unpublished MLS Thesis). University of Nigeria, Nsukka.

Alvi, M. (2016). A manual for selecting sampling techniques in research. University of Karachi, Iqra University. Accessed from: https://mpra.ub.uni-muenchen.de/70218/1/

American Library Association. (2010). Guidelines for university library services to undergraduate students. Author.

Antiwi, I. K. (2009). Problem of library security. The Bauchi Library Experiences International Review. Journal of Academic Librarianship, 21, 363-372.

Anunobi, C. B., \& Okoye, I. B. (2008). The role of academic libraries in universal access to print and electronic resources in developing countries. Library Philosophy and Practice.

Broadhead, R. M. (2002). Theft in academic libraries. New Library World.

Chaney, M. (2004). Security and crime in libraries. Gower Publishing.

Da Veiga, A., \& Eloff, J. H. (2007). An information security governance framework information systems management. Academic Press.

Dalhatu, U. J., \& Adamu, B. M. (1999). academic libraries and the challenges of information provision in the 21 st century: Paper presented at the inaugural NLA General Meeting and Conference Lafia. Nasarawa State.

Edoka, E. E. (2000). Introduction to library Science. Palma Publishing and Links Company.

Evans, G. E. (2000). Developing library and information centre collection. Libraries Unlimited.

Gelfand. (2005). A conceptual approach to the role of the library in developing countries. Education Libraries Journal, 40(3), 13-22.

Greenstein, D. (2000). Digital libraries and their challenges. Library Trends, 45(4), 290-304.

Ifidon, S. (2000). Essentials of management of African university libraries. University Press.

Jato, M. (2005). Causes and effect of delinquent behaviour in academic libraries (kenneth dike library as a case study). Owena Journal of Library and Information Science, 2(1), 25-34.

Kuh, G. D., \& Gonyea, R. M. (2003). The role of the academic library in promoting student engagement in learning. College \& Research Libraries, 64(July), 257. doi:10.5860/crl.64.4.256

Lorenzen, M. (1996). Security issues of academic libraries: A seminar paper presented to the Faculty of College of Education, Ohio University. ERIC: IR055938.

McComb, M. (2004). Library security. RE:view, 51(9), 469-473.

Nkiki, C., \& Yusuf, F. O. (2008). Library and information support for New Partnership for Africa's Development (NEPAD). Library Philosophy and Practices. Available at: https://unllib.unl.edu/LPP/nkiko-yusuf.htm

Ogbonyomi, A. (2011). Preservation policies and conservation in academic libraries: a report of the cambridge university library conservation project. British Library and Information Research Report no. 29.

Oyewusi,F. O., \& Oyeboade, S. A. (2009). An empirical study of accessibility and use of library resources by undergraduates in a Nigerian state university of technology. Library Philosophy and Practice. https://unllib.unl.edu/LPP/oyewusi-oyeboade.htm

Uga, A. D. (2007). Evaluating the use of university libraries in Nigeria: A case study of Michael Okpara University of Agriculture, Umudike. Library Philosophy and Practice An E-Journal. Available at: https://digitalcommons.unl.edu/ libphilprac/ 